\title{
Public Policy as a Cause of Fishing Conflicts and Coping Strategy employed by the Fishermen in Ngaski Local Government, Kebbi State, Nigeria
}

\author{
S. Umar, Birnin-Yauri, H.B and A.I. Illo \\ S. Umar, Department of Agricultural Economics and Extension, Kebbi State University of Science and \\ Technology, Aliero \\ Birnin-Yauri, H.B., Division of Sciences and Vocational Education, College of Basic and Advanced Studies, \\ Yelwa Yauri \\ A.I. Illo. Department of Agricultural Economics and Extension, Kebbi State University of Science and \\ Technology, Aliero
}

\begin{abstract}
Conflicts over natural resources have always played a role in human society, but recent conditions have led to an increase in their intensity, public profile, and complexity. This paper reviews the forestry and fisheries edict of Kebbi State with a view to determine some weaknesses therein, that causes conflict in the sector. The paper also evaluates the coping strategies employed by fishermen to cushion the effects of conflicts. Four (4) fishermen were randomly selected from the selected villages to obtain a total of 48 respondents. The review of the resource use edict of Kebbi State pointed out some contradictory clause which causes conflict between the fishermen and fisheries staff. The result of the study shows that Majority of the fishermen also indicated losses of their income (79.2), yield (72.9), job status (60.4\%) and quality of relationship (59.6) as a result of the conflict. Abandoning fishing and taking other occupations was found to be the most often used problem-oriented coping strategy among fishermen (75.0\%). The study recommends the need for reviewing the Kebbi State Edict to clarify the contradictory clauses indentified in this paper. The work of extension is not limited to teaching of new techniques; it is also instructive to know the obstacles that could stand in the way of the techniques to be adopted by fishermen. It is therefore worthwhile for extension agencies to have units responsible for the management of resource use conflicts.
\end{abstract}

Key Words: Fishermen, Fisheries regulatory agency, Conflict, Public policy, Coping strategy

\section{Background of the Study}

The policy environment for natural resources management has changed dramatically in recent decades. Population growth, agricultural settlement, and growing trade, investment, and economic activity have increased pressure on all resources. Natural resources once used only locally have been appropriated for the manufacture of industrial products (fibers, oils, timber, and minerals) or international foodstuffs (coffee, beef, fruits). Both large-scale resource developments for export and local overpopulation cause resettlement of rural resource users to ever more vulnerable and unproductive sites, in search of land suitable for the agriculture on which they base their livelihood. There are no more "resource frontiers." Virtually every change of land use, new development, or expansion of any resource use now involves conflicts (Ayling and Kelly, 1997). Natural resource use also continues to be an aggravating factor in armed conflicts around the globe and even in cases where the true sources of the conflict may extend beyond disputed resources, resource conflicts are often the most visible and symbolic causes of the dispute (Tungittiplakorn, 1995).

Conflict becomes problematic when societal mechanisms and institutions for managing and resolving conflict break down, giving way to violence. Societies with weak institutions, fragile political systems and divisive social relations can be drawn into cycles of conflict and violence. Preventing this negative spiral and ensuring the peaceful resolution of disputes is a core interest of the international community. The challenge for $\mathrm{UN}$, EU and other international actors is to promote positive social transformation, while mitigating the risks and potential impacts of violent and damaging conflict (UNIFCPA, 2010).

\section{Public policy as a cause of resource use conflict}

An important initial step in identifying potential policy contributions to the management of local resource conflicts is to recognize the ways public policy can exacerbate such conflicts. Tyler (1999) documented ample evidence from case studies of how specific policies, government programs, and their implementation have generated or aggravated conflicts, even when the intention was to reduce the conflict. Such contradictions suggest that the nature and dynamics of local resource conflicts are poorly understood and that conventional 
interventions can be counterproductive. There are, of course, cases where the direct political interests of central or national elites conflict with those of the local, marginalized poor. In these cases, the policy tools of the state may be applied) in a deliberately one-sided fashion. However, two important lessons can be drawn from these political conflicts:

- Even when direct interests clash in the arena of local natural resource use, neither party has a completely free hand.

- For a variety of reasons, and despite the imbalance of political power, a satisfactory solution for either group may require that both parties reconcile their fundamental interests before either can make use of the contested resources. For example, landowners in Copán, Honduras, came to recognize that in spite of their politically powerful position, their own interests would be better served by selling some of their land than by forcing the government to continue the confrontation.

- In a politically lopsided situation, the tools of the state might not be helpful; because of the political conflicts, the government is widely perceived as lacking legitimacy, and any government interventions are likely to exacerbate the problems.

Although fair policy frameworks for natural resource management may be in place, such policies may be ignored or perverted in their implementation under the pressure of influential elites. This situation may persist because of traditional cultural deference, opaque government procedures, or lack of information. Once again, such situations are becoming less tenable, which begins to shift the balance of political power. Policy responses will need to adjust to reflect these changes. There are a variety of other ways in which the direct actions (or inactions) of policy-driven government agencies can contribute to local resource conflicts (Tyler (1999). The resettlement of the communities along the river Niger to establish Kainji dam might therefore be considered as the major reason for the occurrence of incessant conflicts in the study area.

Anthony, (2008), also reported that the problems associated with the existing institutions of the state and how they function in African context makes resolution of disputes difficult. Despite the existence of institutional frameworks that are supposed to guide processes and delivery on essential services, the continued weakening of these institutions, through political mechanization and predatory nature of African elites, working in cohorts with external interests also contributes further to the undermining of stability in Africa. These tendencies exacerbate resources wars and ethnic rivalry. UNIFCPA,(2010) added that in conflict-affected areas, resource use managing institutions have often been weakened, politicized, and de-legitimized, and may not play a constructive role in the resolution of dispute. Weak formal institution is inimical to effective natural resource and user conflicts management and the delivery of expected benefits from the resource.

Historically, conflicts at the local level were often dealt with through customary or traditional dispute resolution mechanisms. Traditional societies did not necessarily share the instrumentalist perspective of the modern global economy. Conflicts not only took place in an economic context in which risk minimization was generally preferred to profit maximization but were also based on culturally specific notions of value and spirituality that defined the sacred, the secular, and the field of play between these. However, with the breakdown of traditional practices and the penetration of global economic forces to the local level, such conflicts now often come under the jurisdiction of the state. The extending reach of the industrial-consumer society has also transformed the definition of natural resource conflicts. In peripheral regions, the state has often acted to assert its authority for reasons of national security, national identity, and nation-building against the interests of local resource users (de Koninck 1994; Michaud 1994). But the state is increasingly constrained in its ability to act unilaterally, even in matters over which it may have constitutional jurisdiction, such as natural resources.

Global information flows can quickly place local conflicts on the regional or world stage. Even in isolated and obscure conflict situations, access to telephone, the Internet, and other electronic communication tools makes it increasingly difficult even for the most authoritarian regimes to stop the release of contradictory information or prevent public scrutiny of conflict interventions. This is becoming a thorny problem for policymakers around the world (Laohasiriwong and Kongdee, 1995, and Posgate, 1998).

Tyler (1999) reported that sectoral agencies typically prepare land and resource plans, zoning strategies, and maps that reflect their own objectives; however, these plans may be contradictory at the local level. This is a particular problem in protected areas, where conservation-oriented managers can gain strong international and national political support for excluding other resource users. This is not just a matter of physical exclusion from the protected area, but also, typically, a case of conceptual and ideological exclusion: other interests have often been assumed to be secondary to the (urgent, imperative, previously overlooked) conservation objectives, and hence it is thought that these other, non-conservationist interests can be ignored by the planners and managers of the protected area. Each of the case studies dealing with protected areas in this paper provides an illustration of how government officials concentrated on their conservation mandate for the protected areas, paying little attention to the legitimacy of other claimants. In Bolinao, even the proposal for a protected marine area exacerbated latent conflicts in the community. Tyler, 1999 added that, similar arguments 
apply where government agencies are charged with resource planning and investment in their own sectors (for example, forestry, agriculture, mining, industrial development). Within the local community, various resource users are represented within different sectors and receive contradictory signals from different government agencies in dealing with the same resource base. In Uruguay, government incentives for industrial agricultural expansion were in conflict with conservation and other resource interests. Government officials are typically unaware themselves of the conflicts and confusion caused by the contradictory regulations, procedures, and plans of their various agencies.

This report clearly reflects one of the causes of conflicts between the various resource use management institutions, and also between the resource users and the management institutions in the Kebbi State. For example, the Kebbi State fisheries edict 1993, section 8 (i), stipulated that "the fisheries extension officers, district heads, village heads, police officers and any other person appointed by the Commissioner of the Ministry of Agriculture, are the authorized officers who may demand from a fisherman a license or permit to fish for the purpose of inspection." The involvement of different officers from unrelated agencies, e.g. Ministry of Agriculture, Ministry for Local Government and the Nigeria Police Force leads to role conflict between the different management agencies.

Another example was the forestry edict section 8 of the Kebbi State, which stipulated that "the duty of reserve settlement officer include inquiry, server or join claims and shall have all powers conferred upon a District Judge. In addition to this, forestry edict 53(i) stipulated that "any forestry officer or police officer not below the rank of ASP may himself or by any Government employee acting under his directions, seize any forest produce reasonably suspected of having been unlawfully obtained or being unlawfully removed. Edict 55(i) stipulated that "it shall be lawful for any forest officer to arrest without warrant any person who may be reasonably suspected or having committed any offence under the forestry law, while the edict section 58 (i) stipulated that where a person is reasonably suspected of having committed an offence against the forestry law, other than section 54, any forestry officer not below the rank of assistant conservator of forest may, instead of taking proceedings against such person in court, receive from such person a sum of money by way of compensation for the offence that he is suspected of having committed together with the value of the forest produce or forestry property in respect of which he was suspected of having committed an offence (Kebbi State Government, 1993). conflicts:

Tyler, (1999) has therefore outlined the following policy weaknesses that result to resource use

1. Inadequate information or consultation - Inadequate or obsolete data and a limited understanding of local resource uses are common problems in many developing countries. Sometimes these problems are not recognized (that is, central-government officials think they understand the situation better than they actually do), but often decisions are made in full knowledge that the available data are inadequate. Surprisingly, even in cases where data gaps are recognized, local consultation is seldom attempted as a way to improve understanding before devising or implementing a policy. As a result, plans and programs may actually worsen the problems they are intended to address. For example, in Laos, government policy supporting community resource management was implemented in such a rigid way that village demarcation or boundary changes created new conflicts (ibid).

2. Discriminatory or unclear tenure policies - Many countries have tenure systems for land and resources that either reflect historical inequities in wealth and political power or have been recently modified to encourage large-scale industrial agriculture and capital investment. The interests of small-scale and marginalized farmers have been widely ignored. As a result, these people become involved in disputes over resources that they have traditionally used or managed, but to which they have no legal claim. Such situations have frequently arisen as a direct result of government policies intended to promote industrial agriculture or forest plantations (ibid).

3. Population displacement and migration - A frequent result of major development projects supported explicitly by government policy is the displacement of resident populations. In many countries, there are also policies supporting (or even forcing) migration and resettlement away from more populous regions to the agricultural frontiers (Tyler, 1999), such as the experience of the Kainji dam resettled communities in Ngaski Local Government. In addition, a variety of regional development policies are intended to attract voluntary migration to target regions of large countries. There are crucial differences between voluntary and involuntary resettlement, but both can lead to deprivation and conflict, even when they are planned and supported financially by government or other project sponsors. The resource conflicts that concern us here typically arise from resettlement to establish Kainji dam. The outcomes of the focused group discussions with the resettled households revealed that, they are not party to established mechanisms for arbitration, benefit-sharing, and managing common property. They are also highly stressed - typically with little knowledge and limited reserves of food or cash. They are forced to be opportunistic in their use of resources, a situation that can degenerate into open access. 
Governments typically underestimate the impact and disruptions caused by resettlement and fail to recognize the conflicts that might arise.

4. A piecemeal approach to reform - In response to local natural resource management concerns or conflicts, many governments have introduced tenure reforms, decentralization of administrative authority, or organizational changes in resource management. However, the scope of the reforms is often limited to the sector of the responsible agency (for example, social forestry, irrigation, dams, etc); with the result that closely related local institutions remain unchanged. Thus, for example, reform of the local-government administrative system in the Philippines has given greater authority to localgovernment units to manage natural resources. However, technical support, planning and coordination, credit, and extension and marketing systems are not equipped to provide the tools to allow them to take advantage of this increased authority. The result can be greater frustration and even increased conflicts, as internal factions or adjacent municipalities follow their own interests or struggle to deal with multiple contradictory projects of different agencies (ibid).

5. Vague policy direction - Policies drafted by central-government officials may be poorly communicated to the local-government agencies responsible for their implementation. Thus, a regulation that may be clear to the officials who developed it and the political authorities who approved it may be interpreted entirely differently by local implementing officials. The sense and intent of the national-level legislation may not be an overriding concern for local officials dealing with the practicalities and constraints of their own situation. Neighboring districts may implement the same laws or regulations in contradictory ways, leading to new conflicts among resource users who were accommodated under previous arrangements (ibid).

6. Inadequate support for reforms - Some elements of reformed or enlightened resource management frameworks are established, however, such reforms are almost always inadequately supported. Decentralization of authority is not accompanied by adequate funding, training, or capacity-building among the officials charged with implementing the policies. As a result, enlightened policies may either fail to be implemented or be implemented very differently at the local level than intended by the policymakers. An essential element in effective policy responses to natural resource conflicts is the ability to recognize and anticipate these kinds of counterproductive government activities. Avoiding or correcting such problems will result in a solid policy base on which to build conflict management processes in natural resource administration. Some of the problems are deeply entrenched in the political system, but simply recognizing them can be a major step on the road to conflict management (ibid).

\section{Methodology}

Ngaski Local Government was created in 1991, with headquarters at Wara. The area is located on latitude $11^{0} 14^{1}-12^{0} 39^{1} \mathrm{~N}$ and longitude $5^{0} 18^{1}-11^{0} 20^{1} \mathrm{E}$. The area is situated in the Guinea Savanna vegetation zone of Nigeria where the average annual rainfall is about $1000 \mathrm{~mm}$. It has a lowest temperature of $29^{\circ} \mathrm{C}$, which occurs in December during harmattan. The highest daily temperature is $39^{\circ} \mathrm{C}$ (Yauri Meteorological Station, 2012). The Local Government has a population of 126,102 (National Population Commission, 2012). Fishing is the second income-earning activities of the people of the study area.

Cluster sampling was used for the study. All the resettled communities under the Kainji Dam project that benefited from the compensation scheme were identified. These served as clusters. Systematic sampling was employed to select four resettled communities from each of the clusters in the Local Government, which gives a total of twelve (12) resettled communities. In each community, the lists of all the resettled fishermen were compiled with the assistance of the village head. Four fishermen were then selected from each village using simple random sampling. A total of forty eight (48) respondents were therefore selected. Coping strategies of fishermen were measured with 20 items on a 5 point Likert scale. These include 10 active problem oriented strategies, six avoidant (or emotion-oriented) strategies and four support-seeking strategies.

Descriptive statistical techniques such as frequency counts and percentages were used to analyze the data.

\section{Results and Discussions}

\section{Conflict Experiences of the Fishermen}

Outcome of focus group discussion with the respondents shows that resource use conflicts in Ngaski Local Government, lead to huge losses in terms of basic necessities of life. Majority of the fishermen also indicated losses of their income (79.2), yield (72.9), job status (60.4\%) and quality of relationship (59.6). Other losses reported by fishermen in the order of occurrence are self esteem, knowledge, stored products, household resource, family/personal health and social support. This is inimical to the spirit of integration of Nigerian tribes and peaceful co-existence. 
The fishermen suffered several negative socio-psychological consequences relating to their respective family lives as a result of traumatic events such as destruction of unlawful fishing equipments, limited food, and shortages of medical supplies. Majority of the fishermen also indicated that they suffered negative sociopsychological consequences in respect of loss appetite for food (64.6\%), staying away from home (62.5), abandonment of fishing (60.4\%), physical exhaustion (58.3\%), marital dissatisfaction (56.3\%) and declining quality of children's education (52.1\%).

\section{Coping Strategies among Fishermen Involved in Conflicts}

The results in Table 1 indicated 'abandoning fishing and taking other occupations' as the most often used problem-oriented coping strategy among fishermen (75.0\%). According to the fishermen, declining fish catch resulting from obnoxious fishing practices forced them to reduce the mesh sizes of their gill nets in order to catch more fish. They added that this practice was declared unlawful in recent years by the State government and the Local Government council leading to arrest and prosecution of the offenders. This makes them to abandon fishing and look for alternative occupations. Reduced fishing effort (72.8\%) was the second most often used POCS among fishermen. The fishermen revealed that as a result of incessant conflicts, they resorted to reducing their fishing efforts, by engaging in fishing during the night time only. This makes them to avoid possible arrest by the fishery management agency or to avoid the destruction of their fishing gill nets by herders' animals, sailing, rowing or fishing boats. Other fishermen indicated working harder/putting additional fishing efforts (68.7\%), borrowing money from friends, relatives or fishermen associations, purchase of new fishing equipment to replace the destroyed ones (64.6\%), use of previous fishing experience (64.6) and buying food stuff for family consumption as their coping strategy. Prepared for the worst/prepared to resist subsequent arrest was also a coping strategy used by some (29.3\%) of the fishermen. To them, the fisheries management agencies enforced fishing regulations to deny them the Gods' given natural resources and thus their means of livelihood. They therefore maintain a position of threatening whoever attempts to arrest them. Discussion with some group of fishermen revealed that:

- During the 1999 Nigeria- German (GTZ) Kainji dam intervention project in 1999, some group of fishermen's wives at Bakin-ruwa island in Ngaski local government, lied naked on their husbands' unlawful gill nets, to stop the intervention team from burning them.

- In 2011, the district head of Zamare (Sarkin Kudun Zamare) in Yauri local government escaped being murdered when he bordered an engine boat to stop/arrest some fishermen that were reported to engage in obnoxious fishing. The fishermen trapped the district head with their fishing net, and threatened to kill him. Fortunately, he was saved by a passing-bye sailing boat.

Conversely, the result also shows that praying for peace was the most frequently used EOCS (70.8\%) among the fishermen. The second most commonly used coping strategy was pretending that the conflict was not bad (70.8\%). The outcome of the focus group discussion with the fishermen revealed that fishing was the major occupation they inherited from their fore-fathers/ancestors, and was also their major means of livelihood. The fishermen added that they had majority of the conflict with the fisheries management institutions that control obnoxious fishing. They therefore regarded the conflicts as part of their life, since they have no any other means of livelihood. Accepting the conflict situation/consequences as an act of fate was found to be the third commonly used emotion-oriented coping strategy among fishermen (64.6\%). Appease of the other party (25.0\%), transfer of aggression (24.9\%) and use of drugs/alcohol (18.7\%) were however, found to be the least EOCS adopted by the fishermen.

Table 1: Distribution of the Fishermen According to Coping Strategies $(n=48)$

\begin{tabular}{llll}
\hline Coping strategy & Used & Uncertain & Not used \\
\hline Problem oriented & & & \\
Working harder & $33(68.7)$ & $5(10.4)$ & $10(20.9)$ \\
Using experience & $31(64.6)$ & $6(12.5)$ & $11(22.9)$ \\
Borrowing money & $31(64.6)$ & $4(8.3)$ & $13(27.1)$ \\
Preparing for the worst & $12(29.3)$ & $5(10.4)$ & $29(60.3)$ \\
Selling fishing equipments & $6(14.6)$ & $4(8.3)$ & $37(77.0)$ \\
Buying food stuff & $31(64.6)$ & $2(4.2)$ & $15(31.3)$ \\
Reducing fishing efforts & $35(72.8)$ & $3(6.3)$ & $12(20.9)$ \\
Shifting to another job & $36(75.0)$ & $2(4.2)$ & $10(20.8)$ \\
Tightening fishing security & $12(29.2)$ & $2(4.2)$ & $32(66.6)$ \\
Using charms & $12(29.2)$ & $5(10.4)$ & $29(60.3)$ \\
Average \% & $(\mathbf{5 1 . 2})$ & $(\mathbf{7 . 9})$ & $(\mathbf{4 0 . 9 )}$ \\
Emotion-oriented & & & $15(31.3)$ \\
Accepting conflict as fate & $31(64.6)$ & $2(4.2)$ & $14(25.0)$ \\
Praying for peace & $34(70.8)$ & $2(4.2)$ & $13(24.9)$ \\
Pretending conflict wasn't bad & $34(70.8)$ & $2(4.2)$ & $34(70.8)$ \\
Transferring of aggression & $13(24.9)$ & $2(4.2)$ & $36(74.9)$ \\
Using drugslalcohol & $9(18.7)$ & $3(6.3)$ & \\
\hline
\end{tabular}




\begin{tabular}{|c|c|c|c|}
\hline Appeasing other party & $12(25.0)$ & $4(8.3)$ & $34(66.7)$ \\
\hline Average \% & $(45.8)$ & (5.3) & $(48.9)$ \\
\hline \multicolumn{4}{|l|}{ Support seeking } \\
\hline Help from relations & $32(66.7)$ & $2(4.2)$ & $12(29.2)$ \\
\hline Help from local leaders & $13(24.9)$ & $2(4.2)$ & $34(70.8)$ \\
\hline Help from local government & $8(16.7)$ & $2(4.2)$ & $38(79.1)$ \\
\hline Sought litigation & $11(22.8)$ & $3(6.3)$ & $34(70.8)$ \\
\hline Average $\%$ & $(32.8)$ & (4.7) & $(62.5)$ \\
\hline
\end{tabular}

* Figures in brackets are percentages of the coping strategies

Table 1 also illustrates that seeking assistance from friends, relatives and fishermen associations was the most commonly used SSCS among the fishermen (66.7\%) to ameliorate the effects of conflict. It was followed by seeking help from traditional institutions (24.9\%), engaging in litigation (22.8\%) and seeking assistance from local government $(16.7 \%)$.

The result of the study shows that social support was the least coping strategy that is less accessible and rarely adopted by the conflicts' actors. Discussion with the respondents revealed that government do not usually offer humanitarian assistance when there is conflicts, but only directs law enforcement agents to engaged in arrests, which also adds to their suffering. However, John, (2001) noted that It is difficult for people to maintain a stable mental state, after conflicts unless certain basic needs were provided to them. First, conflicts actors must be assured access to food, water, clothing, and shelter. Second, their need for physical safety and security must be met. Rapid physical and social reconstruction (e.g., restoring or creating housing, creating jobs, reuniting families, rebuilding communities) is essential to restoring emotional equilibrium and maintaining mental health, at all stages of the response to disaster.

There is no sharp separation of physical and material needs on the one hand, and the psychological needs on the other. At any stage of the response to conflicts, failure to maintain the momentum towards meeting physical and material needs is a direct threat to mental health. Failure to provide for basic needs can be a potent source of traumatic experience caused by the conflicts. In particular, unnecessary evacuation, poor conditions in a shelter or refugee camp (lack of food, water, sanitation, shelter; threats to personal safety), failure to provide adequate housing, uncertainty as to food and water supplies, and separation of family members from one another are themselves potent causes of subsequent mental health. Failure to provide humanitarian assistance by government and related agencies during the aftermath of conflicts in the study area, and the fear of arrest of the conflicts' actors for possible prosecution by the law enforcement agents leads to desertion.

\section{Conclusion}

Conflicts over the use of natural resources and their causes are central issues in Kainji dam area of Ngaski Local Government, because over time they diminish the present and potential contributions of those resources to the goals of economic growth, food security and export competitiveness. Thus, the search for solutions or ways to manage these conflicts is the basis for a solid investment to improve present and future accessibility, productivity and sustainability of the natural resource base for the development of the area. The study analyzes the resource use conflicts in the Kainji Dam Area of Ngaski Local Government, Kebbi State, Nigeria. This study determines some policy issues that lead to the conflicts, effects of the conflicts, and coping strategies employed by the conflicts actors.

Farmer-herdsmen conflicts have persisted for far too long and the various strategies adopted by both groups have brought little or no progress in dousing the tide and impacts of the conflicts. It is important for both groups to adopt more realistic coping strategies. Coping strategies should be incorporated into the mainstream activities of farmer-herdsmen conflict management. Furthermore, the following recommendations are also proffered for

1. There is the need for reviewing the Kebbi State Edict to clarify the contradictory clauses in which various resource users in the local community receive contradictory signals from different government agencies in dealing with the fishing activities.

2. There is need for educational intervention in fishermen-fisheries agency conflict. This could be achieved by creating better awareness of fishing regulations among fishermen, availing extension personnel with conflict coping mechanisms through attendance of related seminar and conferences. By so doing, extension personnel would be able to teach fishermen on the appropriate conflict coping mechanisms.

3. The work of extension is not limited to teaching of new techniques; it is also instructive to know the obstacles that could stand in the way of the techniques to be adopted by fishermen. It is therefore worthwhile for extension agencies to have units responsible for fishermen-fisheries agency relations. 


\section{References}

[1] Anthony O. O. (2008). Political instability in Africa Where the problem lies and alternative perspectives. The African Diaspora Policy Centre, Amsterdam1 Presented at the Symposium 2008: "Afrika: een continent op drift" Organised by Stichting Nationaal Erfgoed Hotel De Wereld Wageningen, 19th of September, 2008. 17pp

[2] Ayling, R.; Kelly, K. 1997. Dealing with conflict: natural resources and dispute resolution. Common wealth Forestry Review, 76(3), $182-185$.

[3] de Koninck, R. (1994). Forest policies in Southeast Asia: taming nature or taming people? In deKoninck, R., ed., Le défi forestier en Asie du Sud-Est. Groupe de recherche en amelioration des céréales, Université Laval, Québec, QC, Canada. pp.3348.

[4] Kebbi State Government, (1993). The Laws of Kebbi State of Nigeria. Prepared under the authority of the revised edition (Laws of Sokoto State of Nigeria), 1979. 739 - 745 pp.

[5] Laohasiriwong, S.; Kongdee, W. 1995. Dispute resolution in Thailand: working together for peace and prosperity. Proceedings of a workshop in Khon Kaen, Thailand, June 1995. Institute for Dispute Resolution, Khon Kaen University, Khon Kaen, Thailand. 45pp.

[6] Michaud, J. (1994). Montagnes et forêts frontalières dans le nord thaïlandais: l'état face au montagnards. In de Koninck, R., ed., Le défi forestier en Asie du Sud-Est. Groupe de recherche en amélioration des céréales, Université Laval, Québec, PQ, Canada. pp. 89-114.

[7] John H. E. (2001). Coping With Disaster. A Guidebook to Psychological Intervention. Sharon McQuaide, M.S.W., Ph.D. Clinical Consultant. P102.

[8] National Population Commission(2012). Report on 2012 population census, Kebbi State, Nigeria. 66pp.

[9] Tungittiplakorn, W. 1995. Highland-lowland conflict over natural resources: a case of Mae Soi, Chiang

Mai, Thailand. Society and Natural Resources, 8(2), 279-288.

[10] Posgate, D. (1998). Rural development and conflict in northeastern Thailand: a background paper. In Armstrong, G., ed., What works? A case study of successful Canadian governance programming in Thailand and Cambodia. Southeast Asia Fund for Institutional and Legal Development, Canadian International Development Agency, Ottawa, ON, Canada. 67pp.

[11] Tyler, S. R. (1999). Policy Implications of Natural Resource Conflict Management. Ottawa, ON: International Development Research Centre, 1999. 33pp.

[12] United Nations Interagency Framework for Coordination on Preventive Action (UNIFCPA) (2010). Capacity Development for Managing Land and Natural Resource. Guidance Notes for Practitioners, prepared by UNDP. 99-101.

[13] Yauri Meteorological Station (2012). National Meteorological Agency, Kebbi State. 13pp. 